\title{
33. ORGANIC GEOCHEMISTRY OF ODP LEG 107 SEDIMENTS (SITES 652, 653, 654, 655) ${ }^{1}$
}

\author{
E. Brosse ${ }^{2}$ and J. P. Herbin ${ }^{2}$
}

\begin{abstract}
The Rock-Eval pyrolysis of rock samples and the elemental analysis of kerogens show clear differences between Messinian black shales and Pliocene-Pleistocene sapropels recovered during ODP Leg 107. The Messinian black shales are characterized by a large variety of compositions which probably reflects a great diversity of depositional and diagenetic paleoenvironments. In contrast, the Pliocene-Pleistocene sapropels, occurring as discrete layers in nannofossil oozes barren of organic carbon, constitute a rather homogeneous group in terms of organic content. A considerable contribution of terrestrial organic matter in the sapropels could mean that an identical phenomenon of terrestrial input has been periodically reproduced in the basin. The maturity and the nature of the organic matter are discussed with respect to anomalous values recorded for $T_{\max }$ parameter.
\end{abstract}

\section{INTRODUCTION}

The cores from Sites 652, 653, 654, and 655 of ODP Leg 107 give a new opportunity to study, in the Tyrrhenian Sea, two types of organic-rich sediments already known in the periadriatic realm and in more oriental parts of the Mediterranean Sea (Drooger, 1973; Carloni et al., 1974; Borsetti et al., 1975; Deroo et al., 1978; Kidd et al., 1978; Cita, 1982).

1. Black shales of Messinian age, in general finely laminated, that occur as subunits of few meters in thickness, in sediments of evaporitic affinities;

2. Sapropels of uppermost Pliocene and Pleistocene age that occur as discrete layers of few centimeters in thickness within more or less marly nannofossil oozes.

The main contribution of the present work consists in the characterization of kerogens, i.e., of the organic residues obtained after chloroform extraction of solvent-soluble organic matter and dissolution of the mineral matrix.

\section{SAMPLES}

Thirty-one samples have been chosen on board ship, for our analyses, based on organic geochemistry data obtained during Leg 107. Seven samples are representative of the Pliocene-Pleistocene sapropels and 23 samples of the Messinian black shales. One sample (107-652A-7R-3, 133-135 cm) is a calcareous ooze which is typical for the host rock surrounding the sapropels (Fig. 1).

\section{The Messinian Black Shales}

From Hole 652A, three samples (107-652A-20R-6, 73-74 cm, from lithologic Unit IV, and 107-652A-37R-5, 111-112 cm, and 107-652A-38R-3, 65-67 cm, from Unit V) have been taken in sequences of gypsum and carbonate-bearing sandy silts or sands, with interlayered calcareous clays or muds, which present a turbiditic character. The others (107-652A-62R-1, 125-127 cm; 107 652A-62R-CC, 2-3 cm; 107-652A-63R-3, 81-82 cm; 107-652A63R-CC, $18-19 \mathrm{~cm} ; 107-652 \mathrm{~A}-64 \mathrm{R}-1,104-105 \mathrm{~cm}$; and 107-652A$64 \mathrm{R}-2,62-63 \mathrm{~cm}$ ) belong to a particular subunit (in Unit V) characterized by thinly laminated brown/black clays, especially

\footnotetext{
${ }^{1}$ Kastens, K. A., Mascle, J., et al., 1990. Sci. Results, Proc. ODP, 107: College Station, TX (Ocean Drilling Program).

2 Synthese Géologique et Géochemique, Institut Français du Pétrole, P.B. 311, 92506 Rueil-Malmaison, France.
}

rich in organic carbon (up to $11.4 \%$ from on-board analyses). The $\mathrm{CaCO}_{3}$ content is highly variable, averaging $\sim 25 \%$.

The three Messinian samples from Hole 653B (107-653B$25 \mathrm{X}-1,129-131$; 107-653B-28X-2, 1-3 cm; and 107-653B-28X-2, $88-90 \mathrm{~cm}$ ) belong to Unit II, composed of various types of sands, silts, and muds interpreted as deposits of restricted marine to evaporitic environments. The $\mathrm{CaCO}_{3}$ content is low $(0 \%$ $20 \%$ ).

Among the 11 Messinian samples of Hole 654A, one (107$654 \mathrm{~A}-28 \mathrm{R}-2,35-37 \mathrm{~cm}$ ) comes from Unit II, of gypsum interbedded with calcareous clay, mudstone, minor sandstor.e, breccia, dolostone, anhydrite, and very rare nannofossil chalk.

The others (107-654A-36R-2, 41-42 cm; 107-654A-37-CC; 107-654A-38R-1, 17-20 cm; 107-654A-38R-1, 126-130 cm; 107654A-38R-1, 130-132 cm; 107-654A-38R-2, 44-46 cm; 107-654A38R-CC; 107-654A-39R-1, 143-145 cm; 107-654A-39R-2, 12-14 $\mathrm{cm}$; and 107-654A-39R-2, 72-73 cm) belong to Unit III, a dark colored, finely laminated, organic carbon-rich claystone and dolomitic to calcareous siltstone, with minor volcanic ash. Radiolaria, sponge spicules, diatoms, and fish teeth are common. In this unit of about $35 \mathrm{~m}$ in thickness, the maximum enrichment in organic matter is observed between $338.6 \mathrm{~m}$ and $341.7 \mathrm{~m}$, in a layer which presents a very black coloration and a mixed sequence of thin laminations and debris-flow structures. In Section 5 of Core 107-654A-40R, asphaltic matter was observed. The material is believed to have been degraded oil, and contains abundant high-molecular weight hydrocarbon compounds $\left(>\mathrm{C}_{36}\right)$. As a whole, the $\mathrm{CaCO}_{3}$ content is lower than in the Pliocene-Pleistocene sediments, but it may reach $60 \%$.

\section{The Pliocene-Pleistocene Sapropels}

Two samples (107-652A-7R-4, 27-29 cm, and 107-652A-9R-2, $93-95 \mathrm{~cm}$ ) come from Unit II of Hole $652 \mathrm{~A}$, a unit of marly nannofossil ooze: they were taken from the fifth (ST5) and the last (ST8) sapropels encountered in the present hole.

One sample (107-653B-8H-3, 99-101 cm) comes from Subunit Ia of Hole 653B, a grey-brown nannofossil ooze with more or less foraminifers and minor mud. Clastic or cineritic layers are common, and sapropelic layers apparently are more diffuse in the sediment than in Hole $652 \mathrm{~A}$.

One sample (107-654A-6R-4, 137-139 cm) comes from Unit I of Hole $654 \mathrm{~A}$, very similar to the deposit described above for Unit I of Hole 653B.

Three samples (107-655A-2H-4, 65-66 cm; 107-655A-3H-1, 139-147 cm; 107-655A-3H-4, 69-71 cm) come from the Pliocene-Pleistocene drilled just above the basement in Hole 655A. 


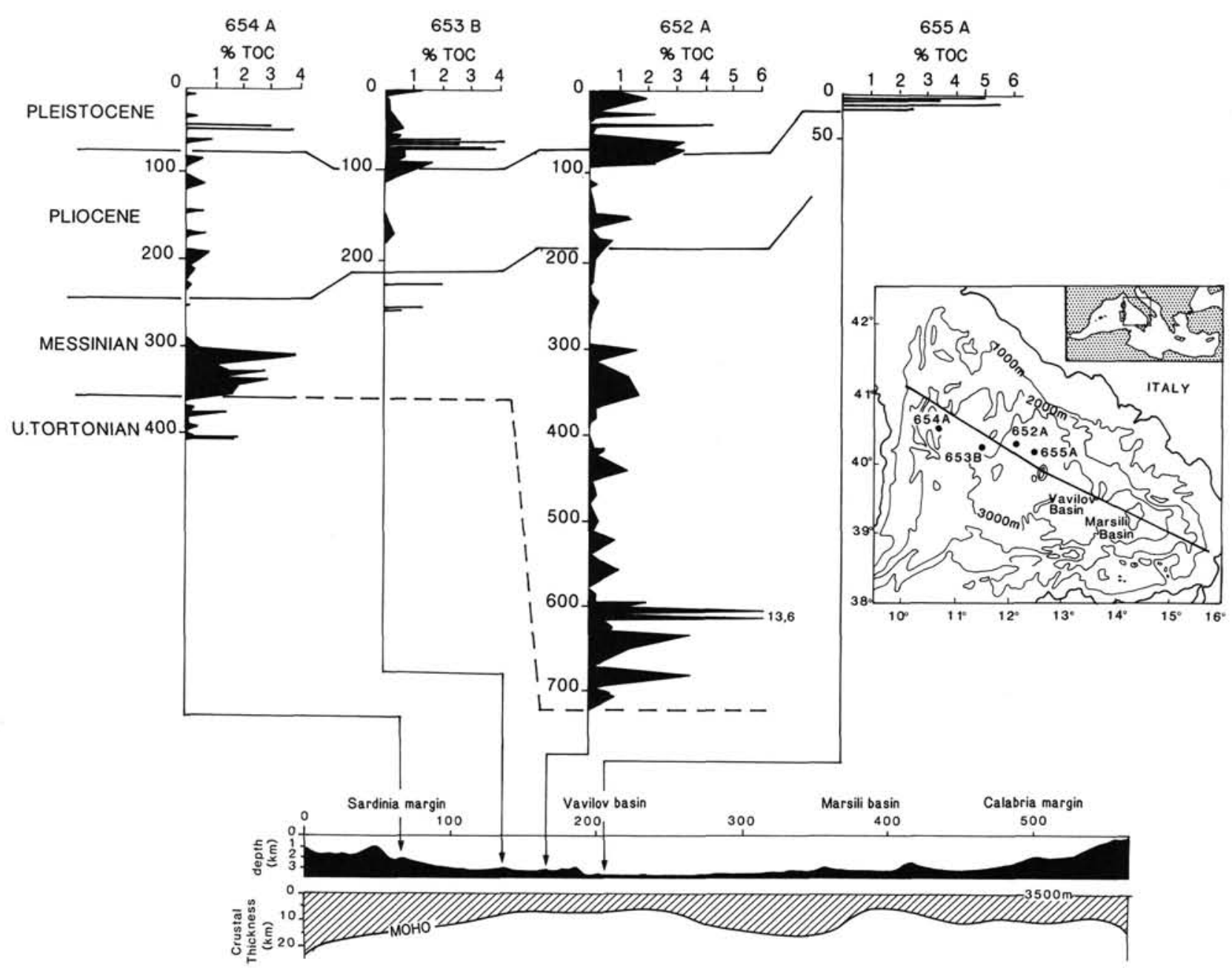

Figure 1. Location of the wells and TOC logs. The location of the four studied wells is given, together with vertical logs of the Total Organic Carbon values, obtained both from our sampling and from shipboard measurements.

This unit is composed of marly nannofossil ooze with occasional volcaniclastic layers and detrital sand layers. Six welldifferentiated sapropels or sapropelic layers were recognized. Among our three samples, the first one is black, the second one is olive-grey, and the last one is dark olive-grey.

All the formations from which the sapropels were taken possess a rather uniform $\mathrm{CaCO}_{3}$ content of about $50 \%$, except in Hole 653B.

\section{ANALYTICAL METHODS}

The 31 whole rock samples $(\mathrm{R})$ were crushed for a Rock-Eval pyrolysis (Table 1) which basically gives (Espitalie et al., 1984, 1985, 1986):

1. Total Organic Carbon (TOC, in weight \%) obtained from combustion of the sample at $600^{\circ} \mathrm{C}$ in the presence of oxygen and detection as $\mathrm{CO}_{2}$ (Fig. 1);

2. The quantity of free hydrocarbons released by vaporization at $300^{\circ} \mathrm{C}$ during $3 \mathrm{~min}\left(\mathrm{~S}_{1}\right.$ in $\mathrm{mg}$ of $\mathrm{HC} / \mathrm{g}$ of rock) ( $\mathrm{HC}=$ hydrocarbons), measured with a Flame Ionization Detector;

3. The quantity of hydrocarbons released during cracking of organic matter between $300^{\circ} \mathrm{C}$ and $600^{\circ} \mathrm{C}$ at a heating rute of $25^{\circ} \mathrm{C} / \mathrm{min}$ ( $\mathrm{S}_{2}$ in $\mathrm{mg}$ of $\mathrm{HC} / \mathrm{g}$ of rock);

4. The temperature corresponding to the maximum flow of hydrocarbons released by cracking $\left(\mathrm{T}_{\max }\right.$, in $\left.{ }^{\circ} \mathrm{C}\right)$;
5. The quantity of $\mathrm{CO}_{2}$ released from organic matter during the first part of cracking, before the decomposition of carbonates $\left(\mathrm{S}_{3}\right.$ in $\mathrm{mg}$ of $\mathrm{CO}_{2} / \mathrm{g}$ of rock).

$S_{1}+S_{2}$ is a parameter which serves usually to quantify the petroleum potential of a rock. Hydrogen Index $\left(\mathrm{HI}\right.$, or $\left.\mathrm{S}_{2} / \mathrm{TOC}\right)$ and Oxygen Index (OI, or $\left.\mathrm{S}_{3} / \mathrm{TOC}\right)$ are used to characterize the chemical composition of the organic matter; in the absence of mineral matrix, for instance in coals, the distribution of the values in a HI-OI diagram is very similar to the distribution obtained in the classical $(\mathrm{H} / \mathrm{C}, \mathrm{O} / \mathrm{C})$ Van Krevelen diagram. $T_{\max }$ is a rank parameter, i.e., it serves to determine the degree of maturation reached by the rock.

The mineral carbon content of the 31 samples (Table 1) has been measured, by complete dissolution in $\mathrm{HCl}$ of the carbonates contained in the crushed rock, and titration with $\mathrm{NaOH}$.

Thirteen samples were chosen for kerogen preparation, because they were representative of the different units, and because they presented sufficiently high TOC values. Firstly they were extracted with chloroform (RAE = rock after extraction), then the solid residue was treated by $\mathrm{HCl}$ and $\mathrm{HF}$ for complete dissolution of the mineral matrix. Finally, the crude kerogen (KB) obtained was extracted again with chloroform, to give an "extracted chloroform KC" which is really the solid organic matter contained in the rock (Durand and Nicaise, 1980). Rock-Eval pyrolysis has been performed on the extracted rocks and on each type of kerogen (Table 1). And the elemental composition ( $\mathrm{C}, \mathrm{H}, \mathrm{O}, \mathrm{N}, \mathrm{S}, \mathrm{Fe})$ of the KC has been measured (Durand and Monin, 1980) (Table 2). 
Table 1. Rock-Eval data for rocks and kerogens. See text for explanation of abbreviations.

\begin{tabular}{|c|c|c|c|c|c|c|c|c|}
\hline $\begin{array}{l}\text { Core, section, } \\
\text { interval (cm) }\end{array}$ & $\begin{array}{l}\text { Depth } \\
\text { (mbsf) }\end{array}$ & NAT & $\% \mathrm{CaCO}_{3}$ & $\begin{array}{l}\text { TOC } \\
(\%)\end{array}$ & $S_{1}+S_{2}$ & $\mathrm{HI}$ & OI & $\mathrm{T}_{\mathrm{MAX}}$ \\
\hline \multicolumn{9}{|l|}{$107-652 \mathrm{~A}-$} \\
\hline $7 R-3,133-135$ & 69.23 & $\mathbf{R}$ & 23 & 0.08 & 0.1 & & & \\
\hline \multirow[t]{4}{*}{$7 R-4,27-29$} & 69.67 & $\mathbf{R}$ & 38 & 1.14 & 1.6 & 132 & 232 & 420 \\
\hline & & RAE & & 3.29 & 9.5 & 265 & 70 & 425 \\
\hline & & KB & & 45.37 & 227.5 & 467 & 91 & 417 \\
\hline & & KC & & 44.70 & 207.3 & 439 & 85 & 417 \\
\hline \multirow[t]{4}{*}{ 9R-2, 93-95 } & 86.63 & $\mathbf{R}$ & 33 & 2.19 & 5.7 & 247 & 186 & 422 \\
\hline & & RAE & & 2.69 & 7.7 & 263 & 143 & 422 \\
\hline & & KB & & 43.47 & 193.4 & 417 & 99 & 415 \\
\hline & & KC & & 39.90 & 184.3 & 437 & 105 & 415 \\
\hline 20R-6, 73-74 & 198.03 & $\mathbf{R}$ & 6 & 0.09 & 0.8 & & & \\
\hline \multirow[t]{4}{*}{$37 R-5,111-112$} & 361.11 & $\mathbf{R}$ & 28 & 1.06 & 0.3 & 19 & 144 & 415 \\
\hline & & RAE & & 0.51 & 0.1 & 12 & 175 & 421 \\
\hline & & KB & & 11.55 & 11.1 & 84 & 103 & 422 \\
\hline & & KC & & 19.13 & 14.7 & 66 & 75 & 426 \\
\hline $38 R-3,65-67$ & 367.35 & $\mathbf{R}$ & 8 & 0.05 & 1.0 & & & \\
\hline $62 R-1,125-127$ & 596.15 & $\mathbf{R}$ & 30 & 0.44 & 0.2 & 32 & 232 & 420 \\
\hline $62 \mathrm{R}-\mathrm{CC}, 2-3$ & 603.92 & $\mathbf{R}$ & 24 & 0.62 & 0.2 & 26 & 153 & 426 \\
\hline $63 \mathrm{R}-3,81-82$ & 608.31 & $\mathbf{R}$ & 22 & 0.56 & 0.2 & 36 & 134 & 425 \\
\hline \multirow{4}{*}{ 63R-CC, $18-19$} & 613.68 & $\mathbf{R}$ & 11 & 6.06 & 40.3 & 621 & 7 & 435 \\
\hline & & RAE & & 4.57 & 23.6 & 514 & 7 & 438 \\
\hline & & KB & & 43.50 & 270.7 & 617 & 11 & 441 \\
\hline & & KC & & 42.00 & 276.8 & 656 & 8 & 443 \\
\hline $64 \mathrm{R}-1,104-105$ & 615.24 & $\mathbf{R}$ & 11 & 13.65 & 129.1 & 890 & 6 & 437 \\
\hline & & RAE & & 11.56 & 89.0 & 767 & 6 & 442 \\
\hline & & $\mathrm{KB}$ & & 52.15 & 434.4 & 828 & 5 & 448 \\
\hline & & KC & & 52.35 & 452.5 & 861 & 4 & 445 \\
\hline $65 R-2,62-63$ & 626.62 & $\mathbf{R}$ & 41 & 1.03 & 0.3 & 31 & 110 & 426 \\
\hline $107-653 \mathrm{~B}-$ & & & & & & & & \\
\hline $8 R-3,99-101$ & 68.89 & $\mathbf{R}$ & 42 & 3.88 & 12.9 & 318 & 146 & 422 \\
\hline & & RAE & & 1.91 & 5.8 & 274 & 175 & 423 \\
\hline & & KB & & 46.93 & 185.4 & 361 & 83 & 417 \\
\hline & & KC & & 51.70 & 177.4 & 322 & 79 & 417 \\
\hline $25 \mathrm{X}-1,129-131$ & 226.99 & $\mathbf{R}$ & 33 & 1.99 & 3.4 & 162 & 331 & 431 \\
\hline & & RAE & & 2.07 & 2.6 & 118 & 235 & 433 \\
\hline & & KB & & 19.05 & 84.9 & 429 & 59 & 421 \\
\hline & & KC & & 20.00 & 84.5 & 414 & 65 & 423 \\
\hline $28 X-2,1-3$ & 256.11 & $\mathbf{R}$ & 16 & 1.24 & 5.9 & 456 & 120 & 416 \\
\hline & & RAE & & 1.70 & 5.4 & 298 & 71 & 422 \\
\hline & & KB & & 33.40 & 169.5 & 476 & 49 & 417 \\
\hline & & KC & & 40.75 & 207.7 & 484 & 42 & 416 \\
\hline $28 X-2,88-90$ & 256.98 & $\mathbf{R}$ & 9 & 0.52 & 1.1 & 198 & 173 & 420 \\
\hline $107-654 \mathrm{~A}$ - & & & & & & & & \\
\hline $6 R-4,137-139$ & 46.17 & $\mathbf{R}$ & 35 & 3.84 & 10.3 & 248 & 171 & 413 \\
\hline & & RAE & & 4.73 & 10.4 & 182 & 124 & 408 \\
\hline & & $\mathrm{KB}$ & & 21.25 & 63.3 & 270 & 98 & 408 \\
\hline & & KC & & 19.85 & 60.5 & 277 & 97 & 409 \\
\hline $28 R-2,35-37$ & 253.85 & $\mathbf{R}$ & 9 & 0.03 & 0.1 & & & \\
\hline $36 \mathrm{R}-2,41-42$ & 311.91 & $\mathbf{R}$ & 47 & 3.72 & 6.2 & 127 & 53 & 362 \\
\hline & & RAE & & 3.20 & 5.1 & 89 & 51 & 370 \\
\hline & & $\mathrm{KB}$ & & 5.65 & 33.0 & 389 & 72 & 360 \\
\hline & & KC & & 5.30 & 24.3 & 318 & 55 & 364 \\
\hline 37. CC & 328.60 & $\mathbf{R}$ & 20 & 1.36 & 4.1 & 218 & 96 & 354 \\
\hline $38 \mathrm{R}-1,17-20$ & 329.47 & & & & & & & \\
\hline & & $\mathbf{R}$ & 11 & 0.89 & 6.2 & 575 & 233 & 402 \\
\hline $38 \mathrm{R}-1,126-130$ & 330.50 & $\mathbf{R}$ & 28 & 1.65 & 3.1 & 142 & 167 & 379 \\
\hline $38 \mathrm{R}-1,130-132$ & 330.60 & $\mathbf{R}$ & 10 & 3.68 & 17.2 & 379 & 82 & 385 \\
\hline & & RAE & & 2.42 & 4.1 & 101 & 101 & 370 \\
\hline & & $\mathrm{KB}$ & & 19.70 & 62.7 & 234 & 55 & 383 \\
\hline & & KC & & 20.78 & 83.5 & 287 & 55 & 380 \\
\hline $38 \mathrm{R}-2,44-46$ & 331.24 & $\mathbf{R}$ & 8 & 2.67 & 20.8 & 698 & 66 & 407 \\
\hline & & RAE & & 1.87 & 11.5 & 451 & 83 & 391 \\
\hline & & KB & & 16.25 & 87.4 & 461 & 50 & 392 \\
\hline & & KC & & 20.35 & 122.8 & 516 & 43 & 392 \\
\hline $38 \mathrm{R}-\mathrm{CC}$ & 338.30 & $\mathbf{R}$ & 25 & 0.83 & 0.6 & 66 & 246 & 399 \\
\hline $39 \mathrm{R}-1,143-145$ & 340.03 & $\mathbf{R}$ & 13 & 1.63 & 7.7 & 418 & 90 & 398 \\
\hline & & RAE & & 1.77 & 7.7 & 342 & 77 & 394 \\
\hline $39 R-2,12-14$ & 340.22 & $\mathbf{R}$ & 31 & 2.54 & 4.9 & 176 & 87 & 395 \\
\hline $39 \mathrm{R}-2,72-73$ & 340.82 & $\mathbf{R}$ & 14 & 2.33 & 5.6 & 215 & 97 & 398 \\
\hline $107-655 \mathrm{~A}=$ & & & & & & & & \\
\hline $2 \mathrm{H}-4,65-66$ & 5.15 & $\mathbf{R}$ & 19 & 4.99 & 15.9 & 300 & 141 & 421 \\
\hline & & RAE & & 5.16 & 12.9 & 222 & 121 & 425 \\
\hline & & $\mathrm{KB}$ & & 45.70 & 169.2 & 333 & 81 & 413 \\
\hline $3 \mathrm{H}-1,139-147$ & 14.09 & $\mathbf{R}$ & 33 & 0.15 & 0.1 & 13 & & \\
\hline $3 \mathrm{H}-4,69-71$ & 17.89 & $\mathbf{R}$ & 20 & 2.35 & 5.9 & 236 & 202 & 422 \\
\hline & & RAE & & 0.96 & 1.6 & 143 & 363 & 419 \\
\hline & & KB & & 2.59 & 5.2 & 173 & 119 & 424 \\
\hline & & $\mathrm{KC}$ & & 2.53 & 5.8 & 201 & 118 & 421 \\
\hline
\end{tabular}


Table 2. Elemental analysis of kerogens KC. See text for discussion.

\begin{tabular}{|c|c|c|c|c|c|c|c|c|c|c|c|c|}
\hline $\begin{array}{l}\text { Core, section, } \\
\text { interval }(\mathrm{cm})\end{array}$ & $\begin{array}{l}\text { Depth } \\
\text { (mbsf) }\end{array}$ & $\mathrm{C}$ & $\mathrm{H}$ & $\mathrm{N}$ & $\mathrm{O}$ & $\mathrm{S}$ & $\mathrm{Fe}$ & ASH. & $\mathrm{H} / \mathrm{C}$ & $\begin{array}{l}\mathrm{O} / \mathrm{C} \\
\times 100\end{array}$ & $\mathrm{~N} / \mathrm{C}$ & $\mathrm{S} / \mathrm{C}$ \\
\hline \multicolumn{13}{|l|}{$107-652 \mathrm{~A}-$} \\
\hline $7 R-4,27-29$ & 69.67 & 50.82 & 5.09 & 2.38 & 16.15 & 11.52 & 9.10 & 15.90 & 1.20 & 23.83 & 3.98 & 0.82 \\
\hline 9R-2, 93-95 & 86.63 & 47.70 & 4.53 & 2.36 & 15.89 & 13.01 & 11.51 & 20.00 & 1.14 & 24.98 & 4.21 & 0.00 \\
\hline $37 \mathrm{R}-5,111-112$ & 361.11 & 22.75 & 1.58 & 0.67 & 10.74 & 29.87 & 25.59 & 43.70 & 0.83 & 35.41 & 2.50 & 1.02 \\
\hline 63R-CC, $18-19$ & 613.68 & 42.21 & 4.78 & 0.70 & 3.84 & 25.39 & 18.39 & 30.40 & 1.36 & 6.82 & 1.41 & 3.83 \\
\hline $64 \mathrm{R}-1,104-105$ & 615.24 & 62.46 & 7.54 & 1.14 & 3.86 & 13.23 & 9.96 & 16.40 & 1.45 & 4.63 & 1.55 & 1.09 \\
\hline \multicolumn{13}{|l|}{ 107-653B- } \\
\hline $8 \mathrm{H}-3,99-101$ & 68.89 & 50.95 & 5.11 & 2.21 & 18.33 & 10.16 & 8.39 & 19.60 & 1.20 & 26.98 & 3.69 & 0.41 \\
\hline $25 \mathrm{X}-1,129-131$ & 226.99 & 23.71 & 2.37 & 0.85 & 8.20 & 33.29 & 24.22 & 43.70 & 1.20 & 25.94 & 3.05 & 8.75 \\
\hline $28 \times-2,1-3$ & 256.11 & 44.05 & 4.65 & 1.61 & 9.63 & 27.27 & 18.47 & 25.40 & 1.27 & 16.40 & 3.11 & 5.18 \\
\hline \multicolumn{13}{|l|}{$107-654 \mathrm{~A}-$} \\
\hline $6 \mathrm{R}-4,137-139$ & 46.17 & 21.84 & 2.04 & 1.09 & 8.92 & 34.00 & 28.11 & 44.40 & 1.12 & 30.63 & 4.24 & 3.18 \\
\hline $36 \mathrm{R}-2,41-42$ & 311.91 & 6.66 & 0.80 & 0.15 & 3.00 & 48.14 & 37.88 & 58.10 & 1.44 & 33.78 & 1.91 & 26.94 \\
\hline $38 \mathrm{R}-1,130-132$ & 330.60 & 24.41 & 2.83 & 0.57 & 8.79 & 35.51 & 24.04 & 38.50 & 1.39 & 27.01 & 1.98 & 12.18 \\
\hline $38 \mathrm{R}-2,44-46$ & 331.24 & 21.34 & 2.65 & 0.57 & 6.86 & 37.87 & 26.11 & 42.10 & 1.49 & 24.11 & 2.27 & 13.92 \\
\hline \multicolumn{13}{|l|}{$107-655 \mathrm{~A}-$} \\
\hline $3 \mathrm{H}-4,69-71$ & 17.89 & 3.27 & 0.61 & 0.15 & 3.59 & 1.91 & 1.59 & 90.20 & 2.24 & 82.34 & 3.90 & 1.05 \\
\hline
\end{tabular}

From the chloroform extracts, the saturated hydrocarbons, isolated by a thin-layer chromatography technique (Huc et al.,1977), have been analyzed by gas chromatography.

\section{CHARACTERIZATION OF THE ORGANIC MATTER IN THE MESSINIAN SAMPLES}

The Messinian deposits of Hole 652A present generally low $(0.5<$ TOC $<1 \%)$ to extremely low (TOC $<0.1 \%$ ) values of Total Organic Carbon, except in the finely laminated black shales encountered around $600 \mathrm{~m}$ depth. In these black shales, TOC reaches $13.65 \%$ and the petroleum potentials are very high (up to $129 \mathrm{~kg} \mathrm{HC} / \mathrm{t}$ of rock) (Table 1 ).

The few Messinian black shales of Hole 653B that have been analyzed present moderate contents of organic carbon $(0.5<$ TOC $<2 \%$ ) (Table 1$)$.

The sample of Unit II in Hole 654A is devoid of organic matter $(\mathrm{TOC}=0.03 \%)$. The other Messinian samples from the very finely laminated black shales of Unit III, present moderate to fair TOC values (between $0.8 \%$ and about $4 \%$ ), with good petroleum potentials (Table 1).

In a $\mathrm{HI}$ vs. OI diagram (Fig. 2), the Messinian sediments are highly scattered. The very organic-rich black shales of Hole $652 \mathrm{~A}$ coincide with the initial evolution path of the classical Type I (Tissot and Welte, 1978). The other samples are disseminated between the Type II and the Type III trends (Tissot and Welte, 1978), and probably reflect a large variety of sources and/or depositional environments. Such a variety is even observed at the scale of individual units of the Messinian sediments, as the lithologic unit III of Hole 654A: sample 107$654 \mathrm{~A}-38 \mathrm{R}-2,44-46 \mathrm{~cm}$, plots at the beginning of Type II path, while $107-654 \mathrm{~A}-38 \mathrm{R}-1,126-13 \mathrm{~cm}$, is near the beginning of the Type III path. Between these two samples, 107-654A-38R-1, $130-132 \mathrm{~cm}$, has an intermediate composition, which probably means a mixing of organic matter from different origin.

This picture is confirmed by the plot of kerogens $\mathrm{KC}$ in a Van Krevelen diagram (Fig. 3). Samples from Hole 652A appear as the most heterogeneous: one sample is located at the beginning of the Type III trend, which serves as a reference for the organic matter derived from terrestrial plants; two samples (the two samples already noticed for their high petroleum potential) are located in an intermediate position between Type I and Type II trends, which serve as reference for organic matter derived re- spectively from algal (especially lacustrine) lipids or from organic matter enriched in lipids by microbial activity, and from marine planktonic biomass (Tissot and Welte, 1978).

The samples from the two other sites appear to be mixtures of a hydrogen-rich end-member (Type I or Type II) and an oxygen-rich end-member (Type III). The difference observed between 107-654A-38R-2, 44-46 cm, and 107-654A-38R-1, 130$132 \mathrm{~cm}$, in the (HI,OI) diagram (Fig. 2) disappears in the Van Krevelen diagram (Fig. 3). Nevertheless this difference cannot be explained by a matrix effect, because $\mathrm{HI}$ of the corresponding $\mathrm{KC}$ are themselves very different from each other (Table 1).

The diversity of organic matter quantities and qualities in the Messinian deposits of ODP Leg 107 reflects a diversity of paleoenvironmental conditions during sedimentation as well as during early diagenesis. This variety has also been observed through nannoplankton study (Müller, this volume): the general evolution in the Tyrrhenian Sea during this epoch is a transition from open marine conditions (Tortonian-lower Messinian) to marine restricted or lacustrine environments (upper Messinian). In such a context, very peculiar situations may develop locally: for instance, Unit III of Hole 654A would have been accumulated under the sea but with possibly high productivity and notable input of terrestrial organic debris (Müller, this volume), while Unit V of Hole $652 \mathrm{~A}$ would have been accumulated, at least in part, under lacustrine conditions.

\section{CHARACTERIZATION OF THE ORGANIC MATTER IN THE PLIOCENE-PLEISTOCENE SAMPLES}

The organic matter present in the discrete sapropelic layers of Pliocene-Pleistocene age, when compared to the Messinian one, gives a totally different picture: in the HI-OI diagram (Fig. 4), as well as in the Van Krevelen diagram (Fig. 5), the samples cluster tightly around an intermediate composition between Type II and Type III. Probably, higher proportions of Type III than of Type II are present in the sediments.

Whatever the way invoked to explain the deposition of sapropels, the organic content of Pliocene-Pleistocene ones reflects a paleoenvironment rather subject to external and relatively terrigenous influences, especially when compared to restrictive conditions developed here and there during Messinian. 


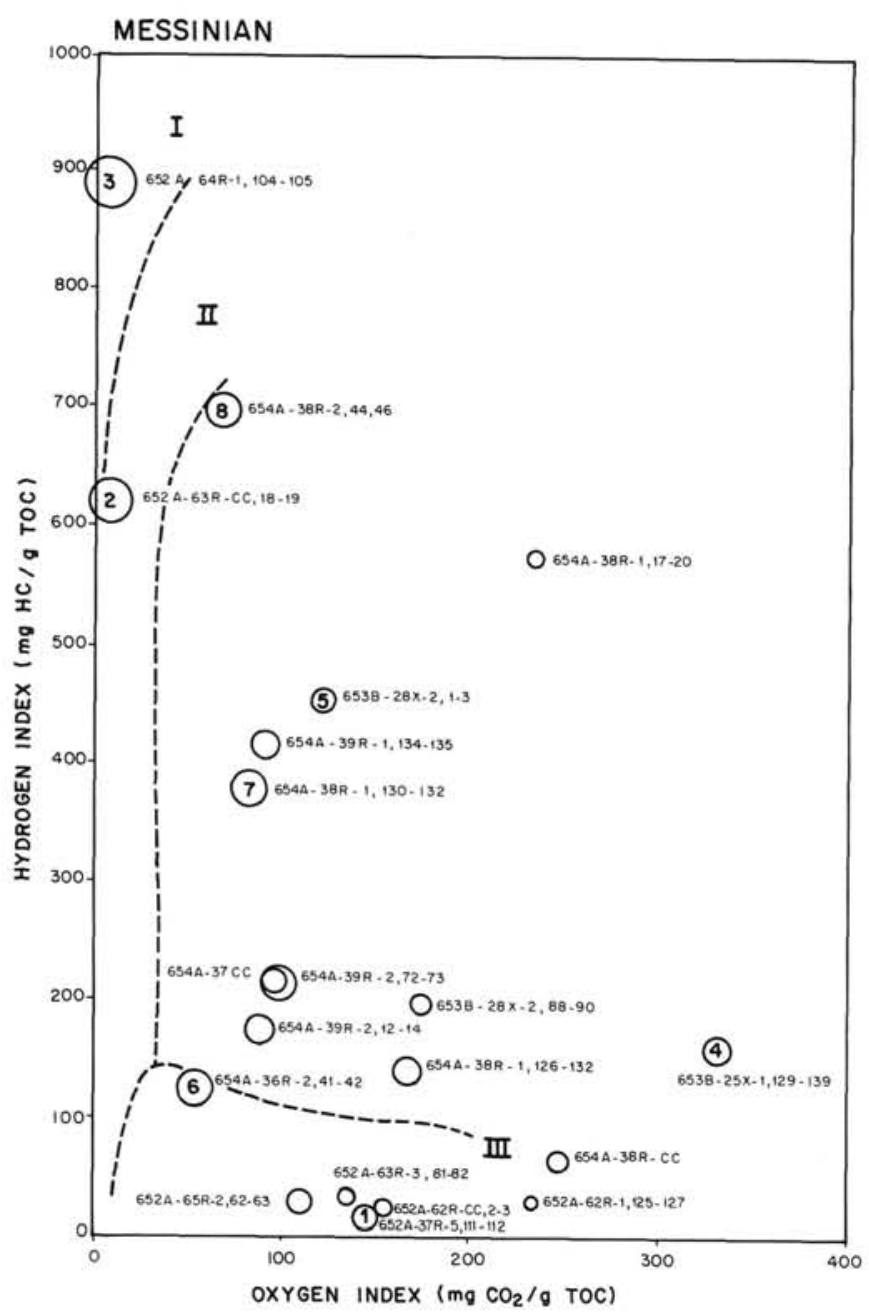

Figure 2. HI vs. OI for Messinian crude rock samples. $\mathrm{HI}$ is the Hydrogen Index $\left(\mathrm{S}_{2} / \mathrm{TOC}\right.$, in $\mathrm{mg} \mathrm{HC} / \mathrm{g}$ TOC). OI is the Oxygen Index $\left(\mathrm{S}_{3} /\right.$ TOC, in $\mathrm{mg} \mathrm{CO} / \mathrm{g}$ TOC). Symbol size is proportional to the TOC value. The numbers in the symbols correspond to the analyzed kerogens (Fig. 3). I, II, and III are the trends defined by Tissot et al. (1974).

\section{DISCUSSION: MATURITY AND NATURE OF THE ORGANIC MATTER}

The pyrolysis temperatures $\mathrm{T}_{\max }$ of most of the samples is less than $426^{\circ} \mathrm{C}$, and consequently the organic matter as a whole may be considered as immature. Nevertheless, several points must be underlined and discussed.

1. A systematic and significant difference does exist between $\mathrm{T}_{\max }$ of the samples which come from Hole $654 \mathrm{~A}\left(\sim 400^{\circ} \mathrm{C}\right)$ and $\mathrm{T}_{\max }$ of the samples which come from other sites $\left(\sim 420^{\circ} \mathrm{C}\right)$.

2. There is no observable $T_{\max }$ increase as a function of depth. In Hole $652 \mathrm{~A}$ for instance, $\mathrm{T}_{\max }$ values for the less buried samples $\left(420^{\circ} \mathrm{C}, 422^{\circ} \mathrm{C}\right.$, at $\left.\sim 69 \mathrm{~m}\right)$ and for the most buried one $\left(426^{\circ} \mathrm{C}\right.$, at $\left.\sim 626 \mathrm{~m}\right)$ are about the same; and very young sediments, such as $107-655 \mathrm{~A}-2 \mathrm{H}-4,65-66 \mathrm{~cm}$, at only $5 \mathrm{mbsf}$, present a comparable $\mathrm{T}_{\max }\left(421^{\circ} \mathrm{C}\right)$.

3. The two black shales of Hole $652 \mathrm{~A}$ which have a very high petroleum potential (107-652A-63R-CC, 18-19 cm, and 107$652 \mathrm{~A}-64 \mathrm{R}-1,104-105 \mathrm{~cm})$ present higher $\mathrm{T}_{\max }$ values than all other samples $\left(435^{\circ} \mathrm{C}\right.$ and $437^{\circ} \mathrm{C}$, respectively).
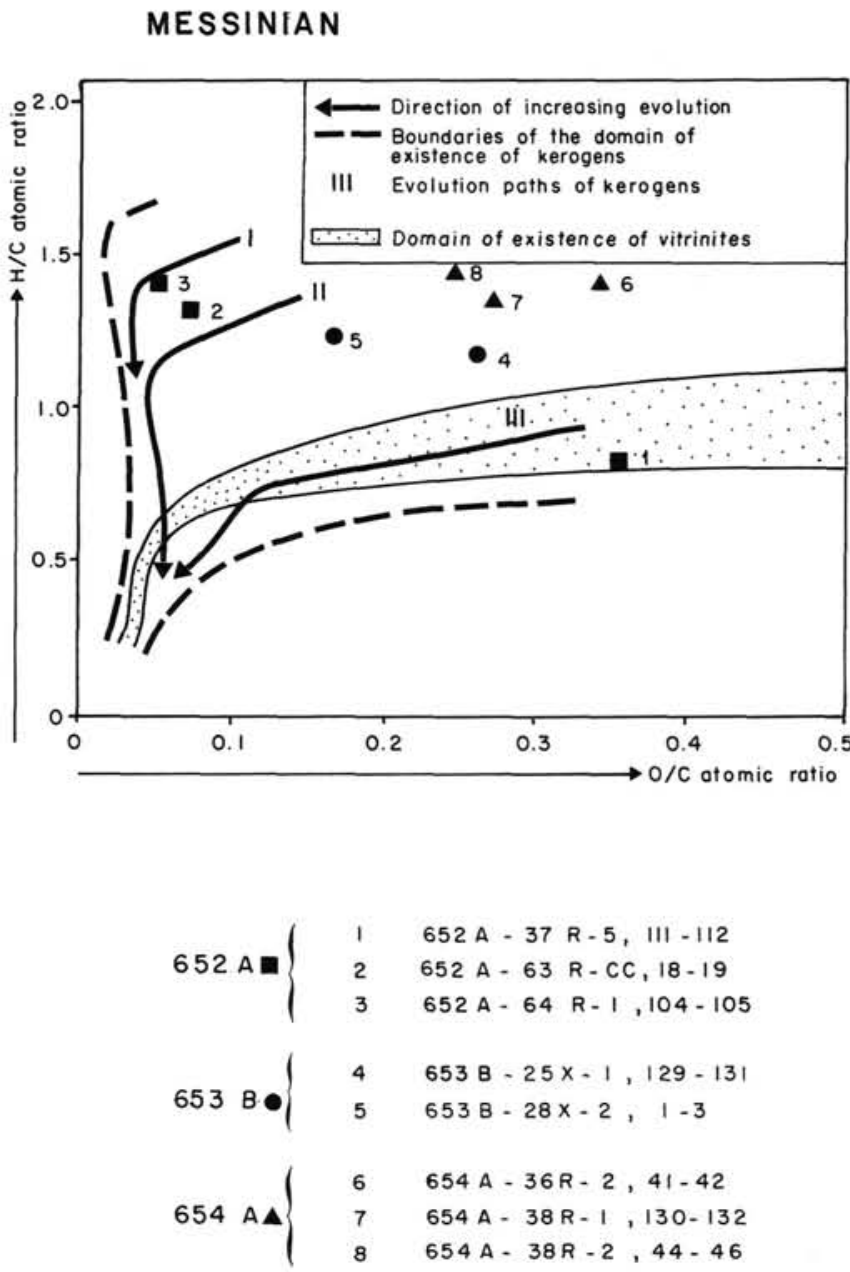

Figure 3. Atomic $\mathrm{H} / \mathrm{C}$ vs. $\mathrm{O} / \mathrm{C}$ for Messinian extracted kerogens.

On the other hand, it has been verified on the pyrolysis diagrams that the $\mathrm{S}_{2}$ peaks are sufficiently well defined to provide a meaningful $\mathrm{T}_{\max }$. The lack of a systematic and important gap between $T_{\max }$ of the crude rocks and $T_{\max }$ of the chloroform extracted rocks, or $T_{\max }$ of the kerogens (Table 1), ensures that these values reflect an intrinsic state of the organic matter. As a consequence, the differences noticed above may be interpreted only in two ways: variations in the nature of the organic content, or differences in the thermal alteration reached by this organic content. As a matter of fact, a very marked difference does exist between heat flows at Site 654 and at the other sites (Kastens, Mascle, et al., 1987) and it seems likely that the lower $\mathrm{T}_{\max }$ of this site can be explained by its relatively moderate thermal regime. Nevertheless the arguments which favor the first interpretation (variations in the nature of the organic content) are stronger according to our present analytical investigation:

1. No correlation of $T_{\max }$ vs. depth;

2. Highest $T_{\max }$ observed for two samples which are characterized by a specific composition in the HI-OI diagram as well as in the Van Krevelen diagram (Figs. 2 and 3), and also by peculiar chromatographic distributions of the saturated hydrocarbon fraction from the chloroform extracts (Fig. 6).

If this interpretation is retained, no clear explanation for the particular case of Hole $654 \mathrm{~A}$ can be given for the moment, be- 


\section{PLEISTOCENE / PLIOCENE}

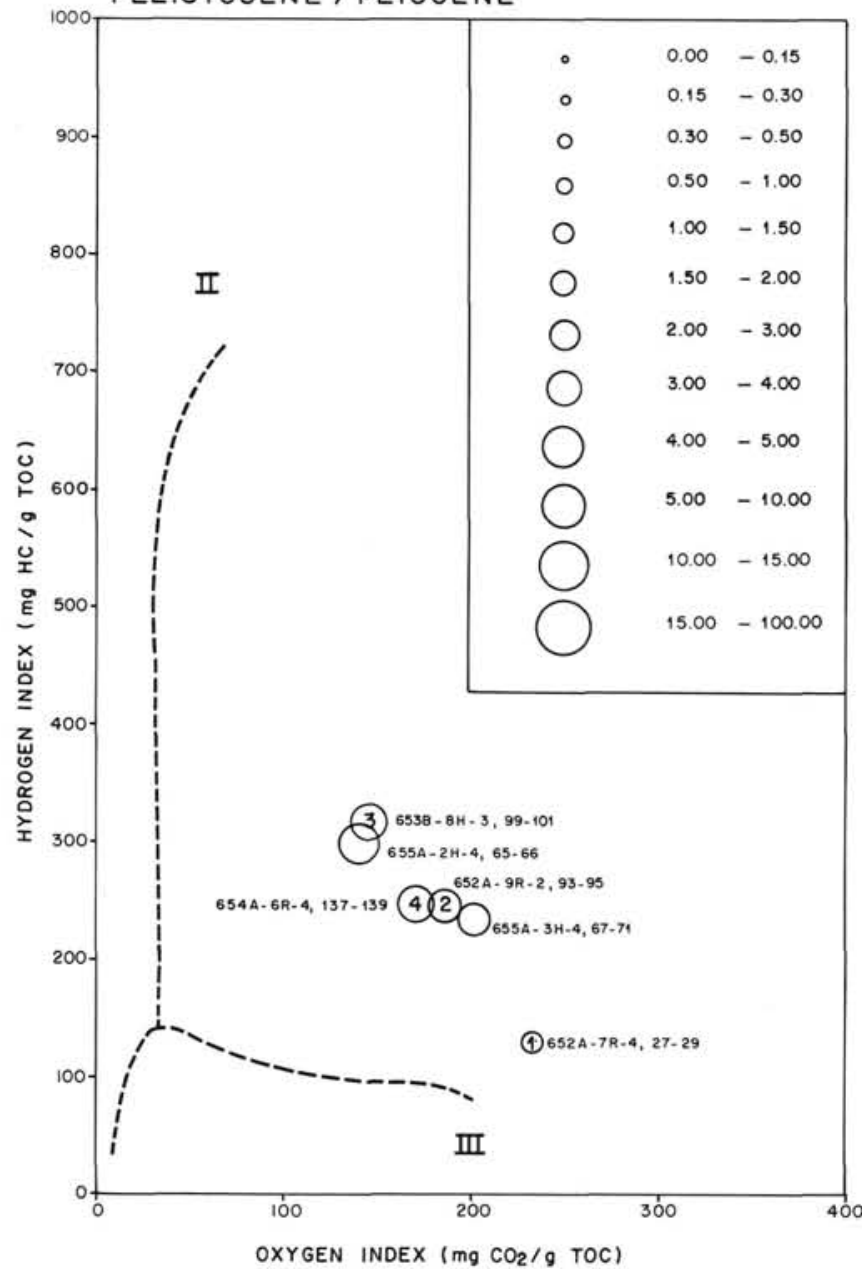

Figure 4. HI vs. OI for Pliocene-Pleistocene whole rock samples.

cause there is no observable evidence, in HI-OI or Van Krevelen diagrams, of a peculiar nature of the organic matter.

\section{CONCLUSION}

The Messinian black shales from Holes 652A, 653B, 654A, and 655B of the ODP Leg 107 (Tyrrhenian Sea) are characterized by a large variety of organic compositions, observed through the Rock-Eval pyrolysis of rock samples and through the elemental analysis of kerogens. This variety probably reflects a great diversity of depositional and diagenetic paleoenvironments, changing from marine to lacustrine conditions with a more or less abundant terrestrial contribution.

In contrast, the Pliocene-Pleistocene sapropels present a rather homogeneous organic content, highly influenced by terrigenous organic matter, but with a systematic participation of marine algal organic matter. This homogeneity probably means a periodic reinstallation of special marine conditions favorable to the preservation of the sedimented organic matter.

\section{REFERENCES}

Borsetti, A. M., Carloni, G. C., Cato, F., Ceretti, E., Cremonini, G., Elmi, C. and Ricci Lucchi, F., 1975. Paleogeografia del Messiniano nei bacini Periadriatici dell'Italia settentrionale e centrale. G. Geol., 40:21-72.
PLEISTOCENE / PLIOCENE

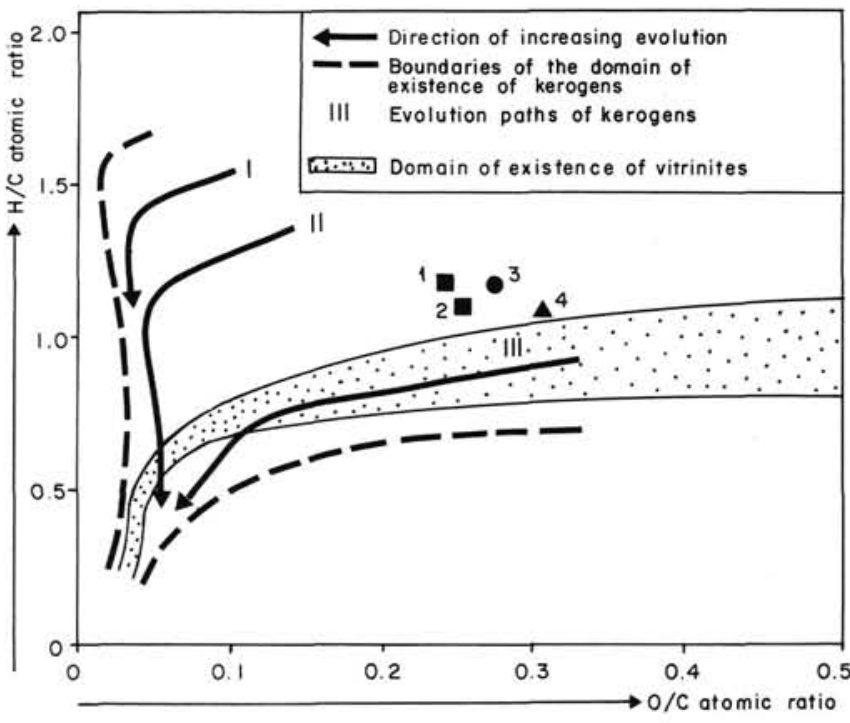

Elemental analysis of the kerogen: $\mathrm{H} / \mathrm{C}$ and $\mathrm{O} / \mathrm{C}$ diagram.

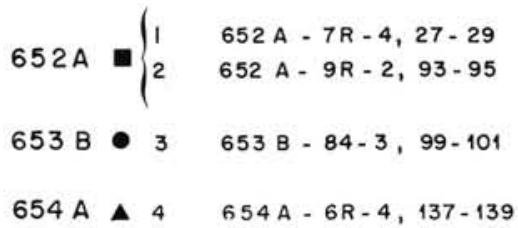

Figure 5. Atomic $\mathrm{H} / \mathrm{C}$ vs. $\mathrm{O} / \mathrm{C}$ for Pliocene-Pleistocene extracted kerogens.

Carloni, G. C., Cato, F., Ceretti, E., Cremonini, G., Elmi, C., and Ricci Lucchi, F., (1974. Messialano Padona Adriatico: descrizione di trenta sezioni rappresentative. Bol. Ser. Geol. It., 95:89-114.

Cita, M. B., 1982. The Messinian salinity crisis in the Mediterranean: a review. In Berckhemer, H., and Hsü, K. J. (Eds.). Alpine Mediterranean Geodynamics: Geodynamic Ser., 7:113-140.

Deroo, G., Herbin, J. P., and Roucache, J., 1978. Organic geochemistry of some Neogene cores from sites 374, 375, 377 and 378: Leg $42 \mathrm{~A}$ Eastern Mediterranean Sea. In Hsü, K. J., Montadert, L., et al., Init. Repts., DSDP 42 (Pt. 2): Washington (U.S. Govt. Printing Office), 465-472.

Drooger, C. W., 1973. Messinian events In the Mediterranean, North Holland Publishing Company.

Durand, B., and Monin, J. C., 1980. Elemental analysis of kerogens. In Durand, B., (Ed.) Kerogen: Technip, 113-142.

Durand, B., and Nicaise, G., 1980. Procedures for kerogen isolation. In Durand, B., (Ed.) Kerogen: Technip, 35-54.

Espitalie, J., Marquis, F., and Barsony, I., 1984. Geochemical logging. In Voorhees, K. J. (Ed.), Analytical Pyrolysis: Butterworth, 276-304.

Espitalie, J., Deroo, G., and Marquis, F., 1985a. La pyrolyse ROCKEVAL et ses applications. Rev. Inst. Fr. du Pétrole, 40:563-579. 1985b. La pyrolyse ROCK-EVAL et ses applications. Rev. Inst. Fr. du Pétrole, 40:755-784.

1986. La pyrolyse ROCK-EVAL et ses applications. Rev. Inst. Fr. du Pétrole, 41:73-89.

Huc, A. Y., Roucache, J., Bernon, M., Caillet, G., and Da Silva, M., 1977. Application de la chromatographie sur couche mince à l'étude quantitative et qualitative des extraits de roche et des huiles. Rev. Inst. Fr. Pétrole, 31:67-98.

Kastens, K., Mascle, J., et al., 1988. ODP Leg 107 in the Tyrrhenian Sea: Insights into passive margin and back-arc basin evolution. Geol. Soc. Am. Bull., 100:1140-1156. 
Kidd, R. B., Cita, M. B., and Ryan, W.B.F., 1978. Stratigraphy of Eastern Mediterranean sapropel sequences recovered during D.S.D.P. Leg $42 \mathrm{~A}$ and their paleoenvironmental significance. In Hsü, K. J., Montadert, L., et al., Init. Repts., DSDP, 42 (Pt. 1): Washington (U.S. Govt. Printing Office), 421-443.

Steinmetz, L., Ferruci, F., Hirn, A., Morelli, C., and Nicolich, R., 1983. A $550 \mathrm{~km}$ long Moho traverse in the Tyrrhenian Sea from O.B.S. recorded $\mathrm{P}_{\mathrm{n}}$ waves. Geophys. Res. Lett., 10:428-431.
Tissot, B. P., and Welte, D. H., 1978. Petroleum formation and occurrence. Springer-Verlag, 1-538.

Date of initial receipt: 18 November 1987 Date of acceptance: 2 December 1988 Ms 107B-115 


\section{GAS CHROMATOGRAPHY OF SATURATED HYDROCARBONS}

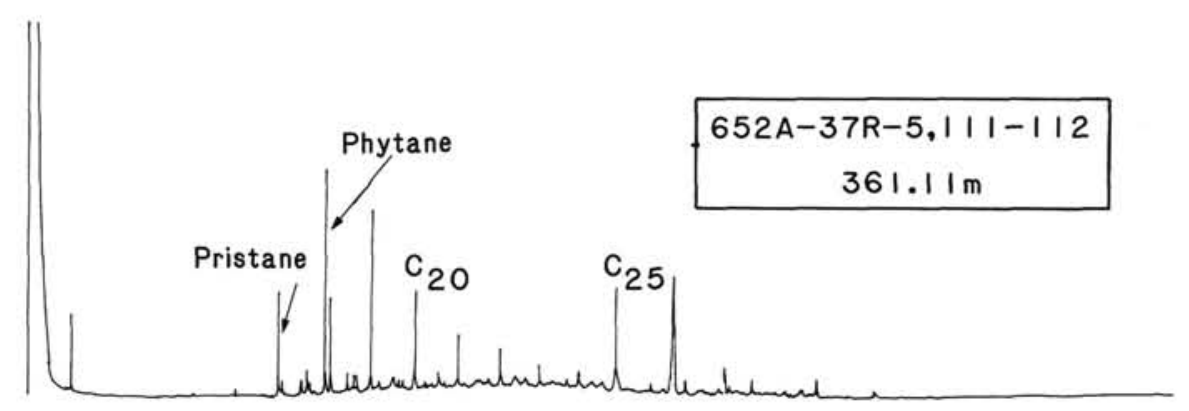

Extract $/ \mathrm{TOC}=2,7 \%$

Saturated $=20,3 \%$

Aromatics $=11,3 \%$

$\mathrm{N}, \mathrm{S}, \mathrm{OComp} .=68,4 \%$
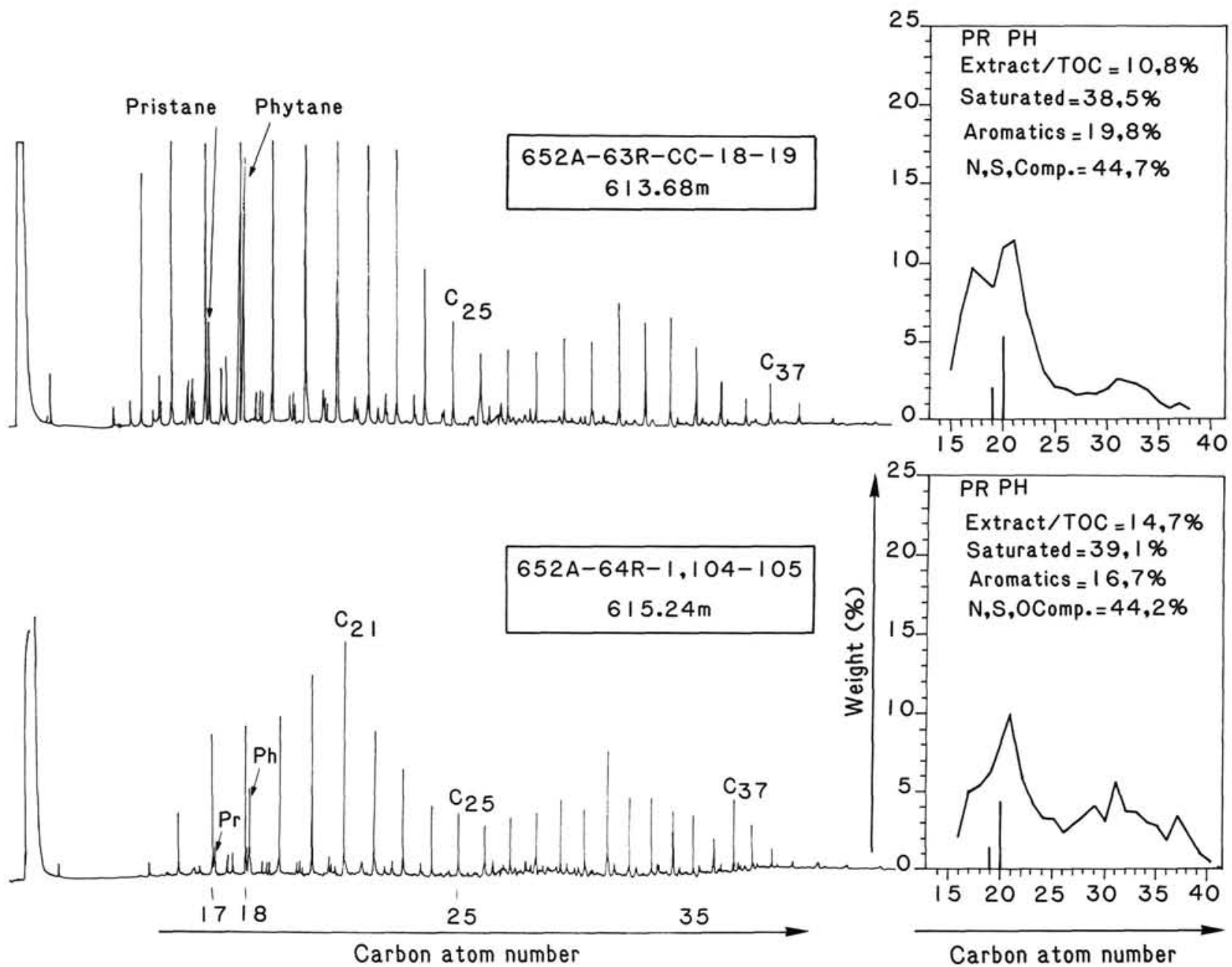

Figure 6. Gas chromatography of the saturated hydrocarbons. In most of the samples (e.g., 107-652A-37R-5, $111-112 \mathrm{~cm}$ ), Extract/TOC is low (few \%), the $\mathrm{N}, \mathrm{S}, \mathrm{O}$, and heavy molecular weight compounds are dominant. In the two Messinian samples of Hole $652 \mathrm{~A}$ which have a very high petroleum potential (107-652A-63R-CC, 18-19 cm, and 107-652A-64R-1, 104-105 cm), Extract/TOC is much more elevated (up to $\sim 15 \%$ ), together with saturates and aromatics fractions, and the gas chromatography of the saturated hydrocarbons give a very extended and well-developed picture, where a moderate odd-carbon-numbered preference and a low pristane/phytane ratio may be noticed. The faint odd-carbon-numbered predominance in the $n$-alkanes of high molecular weight ( $n$ - $\mathrm{C}_{25}$ to $n-\mathrm{C}_{37}$ could be a very discrete fingerprint of continental organic matter: it is well known in oil shales like Green River shale, which serve as a reference series for the Type I kerogen definition (Tissot and Welte, 1978). 